\author{
Contato \\ 6100 Main MS-42 \\ 77005-1827 - Houston - Texas - EUA \\ Humanities \#329 \\ 77251-1892 - P.O. Box 1892 - Houston - Texas \\ https://history.rice.edu/faculty/ludmila-de-souza-maia \\ ludmilasouzamaia@gmail.com
}

\section{PÁGINAS DA \\ ESCRAVIDÃO: RAÇA E GÊNERO NAS REPRESENTAÇÕES DE CATIVOS BRASILEIROS NA IMPRENSA E NA LITERATURA OITOCENTISTA*}

\section{Ludmila de Souza Maia* $^{* *}$}

Rice University

Houston - Texas - Estados Unidos

\title{
Resumo
}

Com a proibição do comércio atlântico de escravos em 1850 para o Brasil, as elites proprietárias tiveram que se adaptar a essa nova realidade, e tanto literatura como imprensa discutiram a questão escrava e seu futuro. Nesse contexto, é perceptível a emergência de uma nova sensibilidade em relação à escravidão, em que se observa a centralidade da mulher escravizada na década de 1850. Eu argumento que tais discussões apresentam um sentido duplo, pois tanto se relacionam com os debates antiescravistas que ocorriam em outras partes do Atlântico, como também com a questão brasileira que se via diante da necessidade de reproduzir a escravidão internamente. Essa análise se baseia nos textos de duas escritoras, a francesa Adèle Toussaint e a brasileira Nísia Floresta, e os discuto em diálogo com outras obras literárias e artigos da imprensa da década de 1850. Este artigo pretende-se, ainda, uma contribuição aos estudos sobre ideias antiescravistas para períodos anteriores à década de 1860 e, principalmente, considera a participação de mulheres nesses debates.

\section{Palavras-chave}

Escritoras - escravidão brasileira - século XIX.

* Gostaria de agradecer a Sidney Chalhoub, Alida Metcalf, Fernanda Pinheiro e Joice Oliveira pelas leituras e comentários feitos em versões preliminares desse artigo. Sou grata também ao Departamento de História de Rice University pelo suporte e pela acolhida durante o pós-doutorado.

** Doutora em História Social pela Unicamp e pela Rice University (2016), com estágio doutoral na École des Hautes Études en Sciences Sociales, Paris, França. Atualmente, é pesquisadora associada ao Departamento de História em Rice University, Houston, TX, Estados Unidos. 


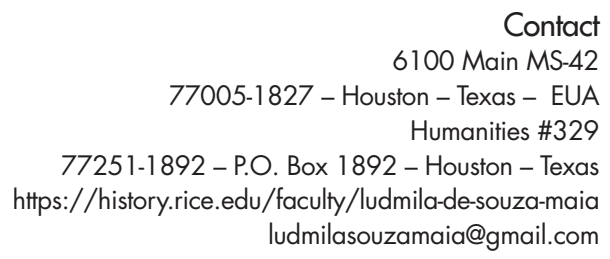

\section{PAGES ON SLAVERY: RACIAL AND GENDER REPRESENTATIONS OF ENSLAVED PEOPLE IN BRAZIL IN MID- NINETEENTH-CENTURY PRESS AND LITERATURE}

\section{Ludmila de Souza Maia}

Rice University

Houston - Texas - United States of America

\begin{abstract}
Due to the abolition of the transatlantic slave trade to Brazil in 1850, slave proprietors had to adapt to a new situation. Literary books and the press discussed slavery and its reduced prospects. In this context, one can observe the emergence of a new sensibility towards slavery, in which the image of enslaved women played a central role. I argue that these discussions have a double meaning in that context, first, they connect to anti-slavery debates from other parts of the Atlantic; second, they relate to the Brazilian context, where the nation faced the need to reproduce slavery internally. I base my analysis on the works of two female-writers, the French Adèle Toussaint and the Brazilian Nísia Floresta. I discuss their works in dialogue with other contemporary literary sources as well as with articles from the press in Rio de Janeiro during the 1850s. This article is also a contribution to the works about anti-slavery ideas in the decades before the 1860s, and considers the involvement of women in such debates.
\end{abstract}

\title{
Keywords
}

Female-writers - Brazilian slavery - nineteenth century. 


\section{Introdução}

No dia 18 de maio de 1856, o jornal francófono do Rio de Janeiro Courrier du Brésil reproduzia na sessão "Cotidiano" (Fait divers) um artigo da Revista Commercial de Santos. O fato ocorrera dias antes durante a liquidação de bens do senhor Francisco José Ribeiro Rato:

Entre os traficantes que assistiam ao leilão, (...) um, em particular, se fez remarcar por um exterior que anunciava um desses indivíduos que perderam todo o sentimento. Este homem, (...) se dirigiu a uma jovem negra grávida que chorava sua desgraçada sorte e em quem se encostava seu filho, um mulatinho. O traficante a interpelou: "Você quer me servir?" A negra pôde apenas lhe responder com palavras entrecortadas por soluços, que sendo criola de Santos, onde ela tinha filhos, não queria ser vendida para os engenhos serra acima. "Tu não queres?" Replicou com um cinismo satânico, o traficante. "Está bem! Eu vou te mostrar se tu tendes vontades, nem que me custe três contos de réis". Depois se dirigindo ao público: "- Que ninguém se atreva, porque essa criatura será minha, custe o que custar!" Um silêncio gélido seguiu suas palavras. A negra foi colocada à venda, o traficante cobriu todos os lances. Seu desejo diabólico fora satisfeito. Em seguida, ele se dirigiu de novo à infeliz negra, com seu sorriso sádico: “Eu não te disse? Agora eres minha! Enforque-se se quiser, aqui está o dinheiro para comprar uma corda" (...) O povo, em silêncio, estremeceu!.'

A cena corriqueira e cotidiana de um leilão de escravos no Brasil assume, no artigo de jornal acima, feições de tragédia. O narrador, logo no início, anuncia o fim macabro da história real com toque de ficção: "entre os traficantes que assistiam ao leilão (...) um em particular se fez remarcar por um exterior que anunciava um desses indivíduos que perdeu todo o sentimento".2 Apresentado o vilão, anuncia-se a tragédia. A vítima era uma jovem mulher grávida, mãe de uma pobre criança, que chorava e soluçava "sua desgraça". Nas imagens da escravidão, uma jovem mulher grávida e indefesa representava um símbolo de vitimização que tinha o intuito de atrair a empatia dos leitores.

A cena real descrita com feições romanescas pelo jornalista da revista toca em uma das temáticas fundamentais de movimentos contrários à escravidão no mundo atlântico na década de 1850 e, ao mesmo tempo, evidencia a

\footnotetext{
1 Minha tradução do original francês. Fait divers. Courrier du Brésil, Rio de Janeiro, 18/05/1856. Disponível em: http://memoria.bn.br/DOCREADER/docreader.aspx?BIB=709719. Acesso em: 03 abr. 2014.

2 Courrier du Brésil, Rio de Janeiro, 18/05/1856. Disponível em: http://memoria.bn.br/DOCREADER/ docreader.aspx?BIB=709719. Acesso em: 03 abr. 2014.
} 
emergência de uma série de críticas nos jornais brasileiros contra a crueldade do cativeiro. O tema da destruição de famílias, apartadas pela venda de seus membros, sobretudo pela separação entre mãe e filho, que dentre todos os laços familiares era o mais inconteste, tornou-se o expoente maior da retórica dos discursos contrários ao cativeiro. ${ }^{3}$ Além disso, a notícia do leilão também alude ao tema do suicídio da escrava, sugerido pelo traficante como a única maneira de escapar do cativeiro. Nesse sentido, a imagem "feminina" da mãe escrava na revista é mobilizada de modo a humanizá-la e trazer o debate sobre o cativeiro para o campo das emoções e da empatia com o público, semelhante às estratégias narrativas desenvolvidas pela literatura ficcional, particularmente nas páginas dos romances. ${ }^{4}$ Ao recorrer à empatia, imagens literárias sobre a feminilidade ganharam vulto como no caso do leilão.

A mesma década de publicação do artigo inicia-se, no Brasil, com a lei que põe fim ao tráfico atlântico de escravos. A lei de 1850 decorria, dentre outras coisas, de pressões internacionais, capitaneadas sobretudo pelos ingleses, que lutavam pelo fim da escravidão. ${ }^{5}$ Com o final da entrada legal de novos africanos, as elites proprietárias do país viram-se obrigadas a se colocar algumas questões fundamentais: como viveria o Brasil sem a escravidão? E mais importante, como os proprietários de escravos poderiam adiar ao máximo essa pergunta? Na década de 1850, autores, e também autoras, reproduziram essas tensões das classes proprietárias geradas pela proibição da importação de novos cativos, tanto em textos ficcionais como naqueles supostamente reais, ditos referenciais, ${ }^{6}$ como no caso de notícias jornalísticas.

No Brasil, as classes proprietárias não consideravam a abolição do cativeiro como algo vislumbrável em um futuro próximo; era, portanto, pouco discutida na maioria dos periódicos brasileiros nos anos 1850. Nesse período, contudo, a escravidão em si ocupava diariamente as páginas de quase todos os jornais do período. Muitos deles, se não eram exatamente contrários à instituição escrava, se mostravam como incansáveis oponentes dos horrores cotidianos que ela produzia ou, ainda, do que muitos chamavam "seus excessos". Jornais como o Courrier du Brésil estampavam cenas dramáticas do

\footnotetext{
MIDGLEY, Clare. Women against slavery: the British campaigns, 1780-1870. Londres e Nova York: Routledge, 1992, p. 119-152.

${ }^{4}$ HUNT, Lynn. A invenção dos direitos humanos. Uma história. São Paulo: Companhia das Letras, 2009, p. 35-69.

5 MIDGLEY, Clare. Women against slavery, op. cit., p. 119-152.

${ }^{6}$ CHALHOUB, Sidney. História contada: capítulos de história social da literatura brasileira. Rio de Janeiro: Nova Fronteira, 1998, p. 103.
} 
cotidiano da venda de escravos, como o caso da mãe no leilão de Santos, e a consequente separação de famílias; agressões cruéis e castigos físicos desmedidos como punição de crimes banais; ou mesmo atos desesperados de escravos que recorriam às agressões ou ao suicídio para escapar do cativeiro. ${ }^{7}$ As críticas à crueldade da escravidão e observações mais gerais sobre a vida dos cativos faziam parte de discursos que extrapolavam os limites da nação e dos gêneros literários em meados do século XIX. ${ }^{8}$ Eu argumento que é possível perceber a emergência de uma nova sensibilidade em relação às pessoas escravizadas ao longo da década de 1850 e isso se evidencia na ficcionalização das cenas cotidianas nos jornais, bem como na verossimilhança das imagens literárias produzidas. No interior dessa nova sensibilidade, destaca-se a centralidade das mulheres que viviam sob o jugo da escravidão.

As elites proprietárias de escravos se engajaram em manter a escravidão até o fim do Segundo Reinado brasileiro, de modo a ter seu domínio sobre os cativos como um direito permanente e indiscutível.9 O comércio interno passou a ser a única fonte de escravos para suprir as demandas de produtores de café do oeste paulista que estavam em franca expansão. ${ }^{10}$ Tal comércio doméstico se intensificou vertiginosamente no Brasil a partir dos anos 1850. Nesse periodo, nos artigos publicados no periódico francófono Courrier du Brésil do Rio de Janeiro, bem como nos textos da década de 1850 da escritora

\footnotetext{
7 Courrier du Brésil. Rio de Janeiro, 18/05/1856. Disponível em: http://memoria.bn.br/DOCREADER/docreader.aspx?BIB=709719. Acesso em: 03 apr. 2014.

8 THERENTY, Marie-Eve. Pour une histoire litteráire de la presse au XIXe siècle. Revue d'histoire littéraire de la France, n. 3, 2003, p. 625-635. Disponível em: https://www.cairn.info/revue-dhistoire-litteraire-de-la-france-2003-3-page-625.htm. Acesso em: 20 jul. 2016. DOI: 10.3917/ rhlf.033.0625. THERENTY, Marie-Eve. Vies drôles et "scalps de puce": des microformes dans les quotidiens à la delle Époque. Études françaises, vol. 44, n. 3, 2008, p. 57-67. Disponível em: https://www.erudit.org/fr/revues/etudfr/2008-v44-n3-etudfr2544/019532ar/. Acesso em: 20 jul. 2016. DOI: http://dx.doi.org/10.7202/019532ar.

9 CHALHOUB, Sidney. A força da escravidão: ilegalidade e costume no Brasil oitocentista. São Paulo: Companhia das Letras, 2012, p. 13-31. MARQUESE, Rafael; PARRON, Tâmis; BERBEL, Márcia. Slavery and politics: Brazil and Cuba, 1790-1850. Albuquerque: University of New Mexico Press, 2016, p. 187-260.

${ }^{10}$ SLENES, Robert. The Brazilian internal slave trade, 1850-1888. Regional economies, slave experience, and the politics of a peculiar market. In: JOHNSON, Walter (org.). The chattel principle: internal slave trade in the Americas. New Haven e Londres: Yale University Press, 2004, p. 325-370.
} 
brasileira Nísia Floresta ${ }^{11}$ e da viajante francesa ao Brasil Adèle Toussaint, ${ }^{12}$ é possível observar como as discussões sobre a escravidão vieram acompanhadas de um sentimento de empatia ou até de simpatia pelos indivíduos que viviam no cativeiro e experimentaram seus horrores. Possivelmente, esse não fosse um discurso hegêmonico sobre a escravidão, mas revela o despertar de novas questões no cenário brasileiro.

Em primeiro lugar, essa sensibilidade traz a crítica ao cativeiro de modo semelhante ao que já ocorria em outras partes do Atlântico e que se relaciona com a circulação de ideias, algo que o jornal francófono da Corte estava engajado em publicar, e de pessoas como as viajantes e escritoras Nísia Floresta e Adèle Toussaint, que viveram o trânsito entre Europa e Brasil. Em segundo lugar, parecia relacionar-se com a ideia de que a própria escravidão dependia da reprodução interna dos plantéis de escravos no interior das fronteiras brasileiras. Não por acaso, essa nova sensibilidade em relação aos indivíduos escravizados trazia uma grande ênfase nas famílias escravas, na defesa de sua humanidade e, particularmente, nas mulheres, as responsáveis por darem a vida ou, aos olhos dos proprietários, reproduzirem escravos ad infinitum, perpetuando assim a escravidão.

Dito isso, este artigo, pretende analisar a emergência dessa nova disposição crítica em relação à escravidão brasileira, a partir dos textos das autoras Nísia Floresta e Adèle Toussaint em diálogo com outras obras, bem como com uma série de artigos publicados no Courrier du Brésil sobre a escravidão na década de 1850. Meu argumento é de que a crítica à escravidão que emerge nesses textos e particularmente sua ênfase na vida das mulheres escravizadas dialoga, paradoxalmente, com movimentos abolicionistas ativos no Atlântico (com grande participação de mulheres) e que pressionaram pelo fim do cativeiro, bem como estão diretamente associados à ideia da

\footnotetext{
${ }^{11}$ Como explico adiante. Nísia Floresta Brasileira Augusta é o nome que ela cunha para si quando se torna autora e publica sua primeira obra em 1832. Contudo, eu prefiro chamá-la, nesse artigo, pela alcunha de Nísia Floresta, pois essa é a maneira pela qual a bibliografia sobre Nísia tem, majoritariamente, se referido a ela. As formas como ela se intitula mudam ao longo do tempo. Ver MAIA, Ludmila de Souza. Viajantes de saias: gênero, literatura e viagem em Adèle Toussaint-Samson e Nísia Floresta (Europa e Brasil, século XIX). Tese de doutorado em História, Instituto de Filosofia e Ciências Humanas, Universidade Estadual de Campinas, 2016.

${ }^{12}$ Adèle Toussaint é seu nome de casada e é a alcunha que ela utiliza para publicar seus textos na década de 1850. Nasceu como Adèle Samson e na viuvez adotou o nome de Adèle Toussaint-Samson. Como esse artigo se refere à década de 1850, escolhi tratá-la pelo nome que mais utiliza nesse período. Ver MAIA, Ludmila de Souza. Viajantes de saias..., op. cit.
} 
centralidade do debate sobre as mulheres escravizadas e suas famílias para a perpetuação da própria escravidão no Brasil.

A maioria dos trabalhos sobre movimentos contrários à escravidão no Brasil iniciam suas análises a partir do final dos anos 1860, quando as discussões sobre o fim da escravidão se tornaram mais evidentes, com a abolição nos Estados Unidos e a criação de associações abolicionistas no Brasil..13 Há célebres trabalhos que analisam os diversos aspectos do processo de emancipação de cativos e dos grupos que se colocaram em defesa do fim da escravidão no Brasil. ${ }^{14}$ A participação das mulheres no processo produziu um número menor de trabalhos, mas tem de forma crescente atraído o interesse dos historiadores e historiadoras do movimento abolicionista, como os trabalhos de Camillia Cowling e Karoline Rocha evidenciam. ${ }^{15}$ Este artigo pretende analisar as críticas à escravidão nos anos 1850, quando a abolição no Brasil não estava na ordem do dia. Nessas discussões, menos ainda tem se falado sobre as mulheres envolvidas nos debates antiescravistas. ${ }^{16}$ Este trabalho se insere em um esforço de recuperar os debates públicos feitos por escritoras sobre a escravidão no Brasil dos anos 1850, dando particular atenção à questão de gênero no interior do cativeiro. Em muitos textos do período, assim como nos das escritoras, é possível perceber um movimento profícuo entre literatura e imprensa, formado por uma dose de ficcionalização da vida representada nos jornais e pela verossimilhança das imagens literárias criadas pelos romancistas e poetas. ${ }^{17}$

\footnotetext{
${ }^{15}$ COWLING, Camillia. Conceiving freedom. Women of color, gender, and the abolition of slavery in Havana and Rio de Janeiro. Chapel Hill: The University of North Caroline Press, 2013, p. 7.

${ }^{14}$ AZEVEDO, Célia Maria Marinho de. Abolicionismo, Estados Unidos e Brasil, uma história comparada (século XIX). São Paulo: Annablume, 2003. Idem. Onda negra medo branco. O negro no imaginário das elites - século XIX. São Paulo: Paz e Terra, 1987. CONRAD, Robert. The destruction of Brazilian slavery, 1850-1888. Malabar, FL: Krieger Publishing, 1993. EL YOUSSEF, Alain. Imprensa e escravidão: política e tráfico negreiro no Império do Brasil (Rio de Janeiro, 1822-1850). São Paulo: Intermeios, Fapesp, 2016.

${ }^{15}$ COWLING, Camillia. Conceiving freedom, op. cit. ROCHA, Karolina Fernandes. Mensageiras da liberdade: mulheres, abolicionismo e recrutamento militar (província do Espirito Santo, 1836-1888). Dissertação de mestrado em História Social das Relações Políticas, Centro de Ciências Humanas e Naturais, Universidade Federal do Espírito Santo, 2016.

${ }^{16} \mathrm{O}$ trabalho de Matthews discorre sobre a relação de Nísia Floresta com a escravidão. MATTHEWS, Charlotte. Gender, race and patriotism in the works of Nísia Floresta. Woodbridge: Tamesis, 2012, p. 121-169.

17 THERENTY, Marie-Eve. Pour une histoire litteráire de la presse au XIXe siècle, op. cit., p. 625635. Idem. Vies drôles et "scalps de puce"..., op. cit.
} 


\section{Escritoras e a separação de famílias na escravidão}

Muitos autores brasileiros e estrangeiros se dedicaram a discutir a escravidão na sociedade brasileira e opinar sobre os destinos da nação, os costumes locais e as relações de trabalho entre senhores e subalternos nos Oitocentos. ${ }^{18} \mathrm{Na}$ década de 1850, a francesa Adèle Toussaint veio para o Brasil com o intuito de "fazer a América", escrevendo durante esse período o que seria publicado como suas memórias, entre outras coisas, sobre as particularidades dos locais em relação aos franceses e, nesse sentido, ressaltando a escravidão como elemento de distanciamento entre Brasil e Europa. Na mesma década, a brasileira Nísia Floresta, educadora e diretora de escola, ao regressar de uma viagem de quase três anos pela Europa, produziu diversas crônicas para a imprensa carioca assim que voltou ao Brasil. Desde o seu retorno, o cativeiro emergiu como tema de reflexão privilegiado de sua pena. Como apontou sua estudiosa Charlotte Matthews, até o retorno da Europa, a escravidão havia sido ignorada em seus escritos, a despeito de ter crescido em uma sociedade escravista. ${ }^{19} \mathrm{Ou}$, talvez, o fato de ter crescido em uma sociedade escravista tenha feita o cativeiro lhe ser algo cotidiano e, consequentemente, invisível.

Nos escritos sobre a escravidão da década de 1850 de Adèle Toussaint e de Nísia Floresta, a despeito das diferenças de estilo literário, período de publicação e nacionalidade das autoras, suas visões do cativeiro no Brasil mostram aproximações fundamentais. As autoras, por exemplo, evitaram agrupar os escravos em categorias homogêneas, preferindo destacar suas complexidades, étnicas inclusive, descrevendo-os enquanto indivíduos que vivenciaram a escravidão de diversas maneiras. Nesse sentido, elas também representaram o cativeiro e suas vítimas a partir da premissa que toma por diversa a experiência de homens e mulheres escravizadas, enfatizando um olhar de gênero sobre as pessoas escravizadas.

A francesa Adèle Toussaint nasceu em Paris em 1820 e cresceu no meio artístico da capital, sendo filha de um dos maiores cantores de ópera do século XIX. Com a revolução de 1848 e o caos social que se seguiu, a família decidiu tentar a sorte do outro lado do Atlântico. Ela chegou ao Brasil em

\footnotetext{
${ }^{18}$ EXPILLY, Charles. Mulheres e costumes do Brasil. São Paulo: Companhia da Editora Nacional, 1935. PFFEIFFER, Ida. Voyages autour du monde. Paris: Hachette et Cie, 1876. TOUSSAINT-SAMSON, Adèle. Uma parisiense no Brasil. Tradução de Maria Lúcia Machado. Rio de Janeiro: Editora Capivara, 2003. ${ }^{19}$ MATTHEWS. Charlotte. Gender, race and patriotism..., op. cit., p. 125-150.
} 
1849 para fazer a América. Veio acompanhada do marido dançarino e de um filho de colo para uma estadia que se estendeu por 12 anos. O marido não teve problema em se estabelecer como artista e instrutor de dança, tornando-se, em poucos anos, o professor das princesas imperiais. Adèle, por sua vez, passou a ensinar línguas estrangeiras particulares e a produzir artigos e poemas para a imprensa. ${ }^{20}$ Entre uma aula e outra, aproveitou para observar os habitantes locais e seus costumes. No período em que viveu no Rio de Janeiro, tomou notas que publicaria no início dos anos 1880 em Paris como um relato de viagem ao Brasil. ${ }^{21}$ Embora Adèle tenha publicado posteriormente, seu texto apresenta indícios de, ao menos, duas temporalidades: a maior parte do texto foi produzida na década de 1850 e recebeu algumas correções e pequenas mudanças no momento de publicação em 1883.

Em suas memórias dessa vivência brasileira, Adèle se interessou particularmente pela sorte de homens, mulheres e crianças que viviam sob o jugo da escravidão no Brasil, afinal, como francesa que era, se mostrara aos leitores pouco familiarizada com o tema antes de sua viagem. A escravidão apareceu nos mais diversos momentos de sua estadia no Rio de Janeiro. Emergiu nas descrições da paisagem carioca, na observação da presença do trabalho escravo em sua vida cotidiana ou mesmo no relato de seus costumes e modos de vida particulares. Por exemplo, a imagem do leilão e a consequente separação de famílias lhe chamou a atenção assim que chegou ao Brasil. Segundo ela: "[e]sse espetáculo da escravidão foi, durante os primeiros anos de minha estadia no Brasil, um dos suplícios de minha vida, e não contribuiu pouco para que pensasse morrer de nostalgia", relembra melancolicamente. Ela conta que "revoltava-se (...) quando (...) passava diante de um daqueles leilões", em que via "pobres negros, em cima de uma mesa, [serem] leiloados e examinados nos dentes e nas pernas como cavalos ou mulas".22 O tratamento animalesco dado aos homens escravizados chocou a sensibilidade da parisiense recém-chegada ao Brasil, constatando que muito do que considerou a barbárie dos trópicos brasileiros advinha de tal nefasta instituição.

Nos anos 1880, quando publicou as memórias em Paris, a imagem retórica do "mercado de carne humana" e os horrores da venda de pessoas como

\footnotetext{
${ }^{20}$ MAIA, Ludmila de Souza. Viajantes de saias..., op. cit., p. 28-60.

${ }^{21}$ A primeira edição em francês: TOUSSAINT-SAMSON, Adèle. Une parisienne au Brésil. Avec photographies originales. Paris: Paul Ollendorff, 1883. BNF, Rez-du-Jardin, Paris. No mesmo ano, a edição recebeu sua tradução em português: TOUSSAINT-SAMSON, Adèle. Uma parisiense no Brasil. Rio de Janeiro: Typographia de J. Villeneuve, 1883.

22 TOUSSAINT-SAMSON, Adèle. Uma parisiense no Brasil, op. cit., 2003, p. 98.
} 
animais já haviam sido exaustivamente denunciados por movimentos contrários àquela instituição em diversas partes do Atlântico. No entanto, Adèle Toussaint transporta para as suas memórias do Rio de Janeiro nos anos 1850 os desconfortos que as cenas do cativeiro traziam à sua sensibilidade europeia, mostrando empatia e compaixão pelos escravos que encontrou no Brasil. Ainda que Adèle não tenha deixado de se utilizar da mão de obra escrava, aliás como fazia a quase totalidade dos brasileiros no período, e como ela mesma reconheceu sem cerimônias em seu relato.

A mesma compaixão com indivíduos escravizados emerge tanto no tratado sobre a educação de meninas quanto nos textos ficcionais, ambos publicados na década de 1850, pela escritora brasileira Nísia Floresta. Nascida na capitania do Rio Grande do Norte em 1810, com o nome de batismo de Dionísia Gonçalves Pinto, ${ }^{23}$ e filha de uma família proprietária de terras e escravos, Dionísia se tornou Nísia Floresta Brasileira Augusta quando publicou seu primeiro livro em 1832, ${ }^{24}$ alcunha que jamais abandonou dentro e fora da vida literária. Antes de fixar residência no Rio de Janeiro no final dos anos 1830, ela havia morado em Pernambuco e no Rio Grande do Sul. ${ }^{25}$ Quando se estabeleceu na Corte, já era viúva e com dois filhos e vivia de seu trabalho de escritora e professora, bem como de rendas herdadas. Na cidade do Rio, dirigiu sua própria escola para meninas que funcionava na região central, quando, no final de 1849, viajou com os filhos para a Europa em um passeio instrutivo que durou pouco mais de dois anos. Viveu na França, onde frequentou cursos no Collège de France e no museu de história natural de Paris. Em seguida, viajou pela Inglaterra, tomada nesse período pelo fervor abolicionista. E, por fim, visitou Portugal, onde cogitou fixar residência, desistindo logo depois. Em cada lugar que passou, frequentou as rodas literárias, artísticas e científicas em busca de instrução. Dentre muitas mudanças que a viagem provocou em sua escrita, sem dúvida, a maior delas

\footnotetext{
${ }^{25}$ Certidão de óbito de Nísia Floresta Brasileira Augusta. Registres Paroissiaux et d'État civil, Mariages, décès, naissance, Décès, 1885 n. 28. Archives departamentales de la Seine-Maritime, Bonsecours-dit Blosseville, Disponível em: http://recherche.archivesdepartementales76. net/?id=viewergdoc=accounts\%2Fmnesys_ad76\%2Fdatas\%2Fir\%2Fserie_E_seigneuries_familles_notaires_etat_civil\%2FFRAD076_IR_E_etat_civil\%2Exml 6 . Acesso em: 20 jan. 2015.

${ }^{24}$ AUGUSTA, Nísia Floresta Brasileira. Dedicatória às brasileiras e aos acadêmicos brasileiros. In: Idem. Direitos das mulheres e injustiça dos homens. 4a edição. São Paulo: Cortez, 1989, p. 21-22.

${ }^{25}$ Atestado de óbito transcrito no artigo de Hilda Flores. FLORES, Hilda Hubner. Nísia Floresta Brasileira Augusta. Letras de Hoje, vol. 27, n. 3, Porto Alegre, setembro 1992, p. 101-113. Disponível em: http://revistaseletronicas.pucrs.br/fo/ojs/index.php/fale/article/view/16073/10546. Acesso em: 13 jul. 2015.
} 
foi um súbito interesse pela escravidão, que se tornou tema nos textos que publicou quando retornou ao Brasil. ${ }^{26}$

No tratado de educação das meninas Opúsculo humanitário de 1853, por exemplo, Nísia Floresta lembra aos leitores da humanidade desses indivíduos escravizados e a existência de famílias no interior do cativeiro "a quem se oprime de trabalho e de maus tratos, negando-se-lhe até a liberdade de refletir, existem mães, filhos, irmãos etc. que sofrem em silêncio sem outra defesa que suas lágrimas (...)",27 revelando empatia e defendendo a existência de laços familiares entre pessoas escravizadas. Opúsculo foi publicado primeiro na imprensa carioca, na seção "Variedades" do Diário do Rio de Janeiro, e só depois foi editado em livro. Nessa obra, Nísia trata da questão da educação de meninas e considera a escravidão como influência nefasta para as famílias brasileiras e, por isso, advoga a retirada dos escravos da vida doméstica. Tal argumento a aproximava de discursos antiescravistas brasileiros da época, que também temiam o vínculo pernicioso dos cativos com as famílias proprietárias. ${ }^{28}$

Dois anos depois, em "Passeio ao aqueduto da Carioca", uma crônica sobre a paisagem da cidade do Rio de Janeiro e de seus arredores, publicada na rubrica "Variedades" do periódico literário O Brasi Illustrado, Nísia Floresta tratou rapidamente do tema da escravidão, colocando nos versos de lamento do trabalhador escravizado em uma pedreira a ideia de exploração desmedida, separação familiar e crueldade dos senhores para com seus escravos. ${ }^{29} \mathrm{~A}$ autora, ao enfatizar a humanidade dos cativos, busca convencer seus leitores a simpatizar com a sorte dos negros, embora não mencione em nenhuma passagem a defesa da abolição.

Outro exemplo de seu interesse pela escravidão é a crônica, de 1855, intitulada "Páginas de uma vida obscura", também publicada em $O$ Brasil Illustrado. ${ }^{30}$ Nísia Floresta denuncia a crueldade e a exploração no interior da escravidão, através da exaltação da bondade do protagonista e escravo

\footnotetext{
${ }^{26}$ MAIA, Ludmila de Souza. Viajantes de saias..., op. cit., p. 61-102. MATTHEWS. Charlotte. Gender, race and patriotism..., op. cit., p. 129.

${ }^{27}$ FLORESTA, Nísia. Opúsculo humanitário. Introdução e notas de Peggy Sharpe-Valadares. São Paulo: Cortez Editora, 1989, p. 161.

${ }^{28}$ AZEVEDO, Célia Maria Marinho de. Onda negra medo branco..., op. cit., 1987, p. 42.

${ }^{29}$ FLORESTA, Nísia. Passeio ao aqueduto da Carioca. O Brasil Illustrado, Rio de Janeiro, 15/07/1855. Disponível em: www.bn.br/hemerotecadigital. Acesso em: 01 jun. 2015.

${ }^{30}$ FLORESTA, Nísia. Páginas de uma vida obscura. O Brasil Illustrado, Rio de Janeiro, 31/03/1855, 15/04/1855, 30/04/1855, 15/05/1855, 31/05/1855, 16/06/1855, 30/06/1855. Disponível em: www. bn.br/hemerotecadigital. Acesso em: 01 jun. 2015.
} 
Domingos. Dentre outros assuntos, a autora aborda o tema da destruição de famílias escravas, mas, dessa vez, com um forte apelo religioso para a questão. A separação familiar aparece através de um dos companheiros de Domingos: "tinha mulher e filhos; venderam-nos quando menos o pensava a diferentes senhores. Minhas lágrimas, minhas súplicas só me obtiveram maiores rigores". ${ }^{31}$ Anos mais tarde, seria o próprio Domingos a ver a mãe de seu filho ser vendida e separada da criança:

Uma santa missão chamou o senhor de Domingos ao estrangeiro e longínquo país. Em sua longa ausência a dedicação do sublime negro para com a parte da família, a cujo serviço ficava, não desmentiu jamais, apesar da cruel provança pela qual passou ele vendo vender a mãe de seu filho durante aquela ausência!32

Apesar dos percalços, o escravo herói não perde suas qualidades e as agruras do cativeiro não deturpam seu caráter superior e nobre, que o transforma em escravo idealizado a partir dos padrões da classe proprietária: passivo, obediente, dedicado, subserviente e, principalmente, cristão. ${ }^{33} \mathrm{~A}$ narrativa nisiana convida o leitor a identificar-se com a sorte dos negros e a humanizá-los por meio de um sentimento de empatia e de um forte componente religioso. A religiosidade de Domingos reforça sua humanidade, de modo a criar um vínculo entre as personagens negras escravizadas e o público leitor, livre e branco, enfatizando a irmandade de todos os cristãos. Contudo, conforme nos aponta Charlotte Matthews, a narrativa também não defende o fim da escravidão, antes luta pela humanização do cativeiro, através da ação de bons senhores. ${ }^{34}$

Possivelmente, Floresta já fosse abolicionista nesse período, mas ao escrever para seus compatriotas, preferia defender apenas a humanização da escravidão e lutar contra suas crueldades em seus textos literários com claros engajamentos políticos. Uma outra alternativa era a de que compartilhasse do desejo da classe proprietária brasileira de manter a escravidão e prolongá-la pelo maior tempo possível, como defendeu Charlotte Matthews em sua análise sobre Nísia. ${ }^{35}$ Prefiro argumentar que as obras de Floresta são cheias

\footnotetext{
${ }^{31}$ FLORESTA, Nísia. Páginas de uma vida obscura. In: DUARTE, Constância (org.). Inéditos e dispersos de Nísia Floresta. Natal: EdUFRN, 2009, p. 62-63.

${ }^{32}$ FLORESTA, Nísia. Páginas de uma vida obscura. In: DUARTE, Constância (org.)..., op. cit., p. 33-44.

${ }^{3}$ Para uma análise literária aprofundada e muito pertinente de "Páginas de uma vida obscura", ver: DUARTE, Constância. Nísia Floresta: vida e obra. 2a edição. Natal: EdUFRN, 2008, p. 100-140.

${ }^{34}$ MATTHEWS. Charlotte. Gender, race and patriotism..., op. cit., p. 130

35 Idem, p. 135.
} 
de ambiguidades. Seus textos se inserem no debate posterior ao fim do tráfico, quando os diversos grupos políticos discutiam o futuro da escravidão e as alternativas para substituí-la ou prolongá-la, em um momento em que poucos diziam-se favoráveis à escravidão, mas que a maioria era contra o fim do sistema escravista. Suas crônicas de O Brasil Illustrado da década de 1850 são contribuíções literárias para um público leitor mais refinado e preocupado com entretenimento e instrução mais do que com informações do cotidiano. Na publicação do tratado de educação no Diário do Rio de Janeiro, uma das folhas mais importantes do período, Nísia intervinha diretamente nos debates da grande imprensa, dessa vez recorrendo a um discurso mais científico do que literário e atingindo um maior público. Em ambos os casos, ela utilizou seus escritos para se posicionar nos debates sobre a escravidão que estavam em curso.

Nísia Floresta, assim como Adèle Toussaint, toca no tema da separação de famílias escravas através da venda de seus entes. Nísia se mostra particularmente contrária à ideia corrente no período de que os negros seriam incapazes de formar famílias ou criar laços afetivos sólidos, argumento utilizado com frequência para justificar a escravidão. ${ }^{36}$ Mesmo tipo de obsevação se apresenta nos relatos de Adèle, quando menciona a separação entre mãe e filho no leilão. Nos anos 1850, a crítica a essa retórica ainda parecia ter pouca força no cenário brasileiro, mas desde o fim do tráfico atlântico já havia discursos públicos contrários à separação de famílias, semelhantes ao de Nísia. ${ }^{37}$ É plausível que a escritora brasileira tivesse trazido, em sua bagagem, ideias abolicionistas em circulação no continente europeu.

No Brasil, durante a década de 1850, houve, por duas vezes, discussões de um projeto de lei contra a separação de casais escravizados, ${ }^{38}$ que só se tornaria lei no final dos anos $1860 .{ }^{39}$ Nísia crescera em uma família proprie-

\footnotetext{
36 SLENES, Robert. The Brazilian internal slave trade, $1850-1888 \ldots$, op. cit., p. 325-370.

${ }^{37}$ Courrier du Brésil, Rio de Janeiro, 15/02/1857, edição 7; 18/05/1856, edição 20; 21/08/1859, edição 34. Disponível em: http://memoria.bn.br/DocReader/docreader.aspx?bib=709719\&pasta=ano\%20185\&pesq=. Acesso em: 04 fev. 2014.

${ }^{38}$ CHALHOUB, Sidney. A força da escravidão..., op. cit., 1993, p. 27.

${ }^{39}$ No dia 15 de setembro de 1869 foi promulgado o art. $2^{\circ}$ do Decreto 1.695, o qual determinava que "Em todas as vendas de escravos, ou seja, particulares ou judiciais, é proibido, sob pena de nulidade, separar o marido da mulher, o filho do pai ou mãe, salvo sendo os filhos maiores de 15 anos". Anos mais tarde, quando da promulgação da Lei do Ventre Livre, a preocupação com a separação de famílias escravas voltou a ser contemplada no artigo $4^{\circ}$ da Lei $\mathrm{n}^{\circ} 2.040$ de 28 de setembro de 1871. De acordo com os parágrafos 7. "Em qualquer caso de alienação ou transmissão de escravos, é proibido, sob pena de nulidade, separar os cônjuges e os filhos
} 
tária de terras e escravos e, sem dúvida, se beneficiava do trabalho compulsório em seu cotidiano, uma vez que a vida na Corte dos anos 1850 nele se fundamentava. ${ }^{40}$ Contudo, desde sua viagem ao além-mar, lançou novos olhares à metade da população carioca que, até então, pouco espaço ocupara em sua pena. No caso de Adèle, foi também uma viagem que a fez descobrir o tema da escravidão, pois enquanto parisiense, se dizia surpresa ao constatar a presença escrava no Rio de Janeiro assim que chegou, mas sua surpresa não a impediu de empregá-los como ela própria admite em suas memórias. ${ }^{41}$

Em realidade, as viagens das autoras e também a circulação de textos no Atlântico influenciaram a produção escrita de Nísia e Adèle no que concerne à escravidão. ${ }^{42}$ No caso de Floresta, ela demonstrou, na narrativa de "Páginas de uma vida obscura", que era capaz de absorver rapidamente influências externas. No texto sobre o escravo Domingos, que foi publicado dois anos depois da primeira edição do romance A cabana do pai Tomás da escritora americana Harriet B. Stowe, ela evidencia explicitamente a semelhança entre seu protagonista Domingos e Tomás, o protagonista do romance estadunidense. ${ }^{43}$

A obra de Stowe obteve enorme sucesso e repercussão, particularmente no Atlântico norte, mas ecoou em outras partes do mundo, ${ }^{44}$ como o caso de Nísia nos revela. A denúncia contra a separação de mães e filhos encontrou eco no público leitor feminino transformando essas questões em pauta de mobilização, ${ }^{45}$ com as quais Nísia teve contato enquanto realizou sua viagem

\footnotetext{
menores de doze anos do pai ou da mãe", e $8 .^{\circ}$ "Se a divisão de bens entre herdeiros ou sócios não comportar a reunião de uma família, e nenhum deles preferir conservá-lo sob seu domínio, mediante reposição da quota, ou parte dos outros interessados, será a mesma família vendida e o seu produto rateado". Ver art. $2^{\circ}$ do Decreto $1.695,15 / 09 / 1869$ e art. $4^{\circ}$ da Lei ${ }^{\circ}$ 2.040 de 28/09/1871. Disponível em: http://www2.camara.leg.br/legin/fed/decret/1824-1899/ decreto-1695-15-setembro-1869-552474-publicacaooriginal-69771-pl.html ; http://www.planalto.gov.br/ccivil_03/leis/LIM/LIM2040.htm. Acesso em: 06 abr. 2016.

${ }^{40}$ Diário de Pernambuco, Recife, 12/09/1828. Disponível em: http://memoria.bn.br/DocReader/ docreader.aspx?bib=029033_01\&pasta=ano\%20182\&pesq=1828. Acesso em: 02 set. 2014. Para mais informações ver MAIA, Ludmila de Souza. Viajantes de saias..., op. cit.

${ }^{41}$ TOUSSAINT-SAMSON, Adèle. Uma parisiense no Brasil..., op. cit., 2003.

${ }^{42}$ MAIA, Ludmila de Souza. Viajantes de saias: escritoras e ideias antiescravistas numa perspectiva transnacional (Brasil, século XIX). Revista Brasileira de História, São Paulo, vol. 34, nº 68, 2014, p. 61-81.

${ }^{43}$ RIBEIRO, Aline Vítor. Harriet Beecher Stowe e Nisia Floresta: abolição e traduções culturais nos Estados Unidos e Brasil. In: ENCONTRO INTERNACIONAL DA ANPHLAC, XI, 2014, Niterói. Anais. São Paulo, USP, 2014. ISNB 978-85-66056-01-3. Disponível em: http://anphlac.fflch.usp. br/sites/anphlac.fflch.usp.br/files/Aline\%20Vitor\%20Ribeiro.pdf. Acesso em: 20 jul. 2016.

${ }^{44}$ MIDGLEY, Clare. Women against slavery..., op. cit., 1992, p. 119-152.

${ }^{45}$ A retórica da maternidade e da família escrava tornou-se um tema importante nos movimentos abolicionistas no Brasil dos anos 1880, sobretudo em manifestações contrárias à escravidão
} 
pela Europa entre 1849 e 1852. Depois de viver na França, seguiu para a Inglaterra, onde conheceu o latente movimento abolicionista inglês, com forte participação de mulheres.

Em 1850, por exemplo, a militante inglesa Anna Richardson convenceu um ex-escravo americano, o reverendo Henry Highland Garnet, a ir à Grã-Bretanha para palestrar pela Inglaterra de modo a promover a participação de mulheres na causa antiescravidão. Ele obteve enorme sucesso e 26 novas associações foram criadas após sua turnê. Nísia Floresta e os filhos devem ter acompanhado na imprensa notícias dessas palestras ou das inúmeras associações que buscavam acabar com o tráfico e com a própria escravidão em todo o Atlântico. Segundo Matthews, nessa época, Nísia deve ter escutado enormes críticas contra seu país e os Estados Unidos, as maiores nações escravistas do Atlântico. Entre 1851 e 1852, o movimento abolicionista foi sacudido pelo estrondoso sucesso do romance americano de Stowe, que foi publicado como folhetim no jornal The National Era e em livro em 1852. Em um ano, o livro bateu o recorde de mais de um milhão de cópias. Na temporada de Nísia entre a França e a Inglaterra, sem dúvida ela conheceu a obra polêmica que tematizava a vida de um escravo herói. ${ }^{46}$

A narrativa de Harriet Stowe reproduziu a tensão do mundo da escravidão através da vida da personagem Tomás, um escravo cristão, vítima impassível dos padecimentos do cativeiro. A trama do romance recria, por meio da história de Tomás, o deslocamento em massa de pessoas escravizadas da região mais ao norte do sul escravista (Upper South) para o chamado sul profundo (região de expansão da escravidão) decorrente do comércio interno de escravos nos Estados Unidos no período anterior à guerra civil. ${ }^{47}$ Assim como no caso brasileiro, devido ao aumento do tráfico doméstico, cenas de leilões se repetiram e foram assim representadas pela autora em seu romance, na ocasião de uma das vendas de Tomás:

presididas por mulheres. Sobre isso ver COWLING, Camillia. O fundo de emancipação "Livro de ouro" e as mulheres escravizadas: gênero, abolição e os significados da liberdade na Corte, anos 1880. In: CÔRTES, Giovanna; FARIAS, Juliana; GOMES, Flávio (org.). Mulheres negras no Brasil escravista e do pós-emancipação. São Paulo: Selo Negro Edições, 2012, p. 213-226.

${ }^{46}$ MIDGLEY, Clare. Women against slavery ..., op. cit., p. 125. Publicações a pedido. Diário do Rio de Janeiro, Rio de Janeiro, 17/02/1852. Disponível em: www.bn.br/hemerotecadigital. Acesso em: 01 jun. 2015.

${ }^{47}$ JOHNSON, Walter. Soul by soul: life inside the antebellum slave market. Cambridge e Londres: Harvard University Press, 1999. 
Subitamente, [Tomás] viu aproximar-se, por entre as turbas, um homem gordo, musculoso e atarracado, a cabeça redonda eriçada de cabelos avermelhados. (...) As mãos eram enormes, peludas e sardentas, guarnecidas de unhas muito sujas e compridas. Tomás logo que o viu, sentiu por êle [sic] horror e repugnância. O homem examinou, sem cerimônia, cada um dos pretos. Chegou-se a Tomás, abriu-lhe a bôca [sic], apalpou-lhe os músculos dos braços ${ }^{48}$ [grifos meus].

Semelhante à descrição de Adèle, na obra de Stowe, o herói passa pela humilhante cena de venda, sendo visto, tocado e avaliado como um animal de carga. E o vilão do romance é também um traficante e senhor de cativos, cuja descrição física sugere seu caráter infame, em um movimento semelhante ao que seria utilizado pelo jornalista do artigo da revista de Santos que abre este artigo. Literatura e imprensa discutiam o mesmo assunto e repetiam as mesmas representações do cativeiro.

As cenas de A cabana do pai Tomás parecem ter servido como um reservatório de imagens literárias e situações dramatizáveis que deram o tom da ficcionalização de situações cotidianas da escravidão. ${ }^{49}$ Isso, sem dúvida, ocorreu graças ao seu enorme sucesso de público e às inúmeras traduções que rapidamente recebeu. Embora o romance americano tenha tido enorme impacto nos discursos contrários à escravidão, ele não foi o único a condenar o cativeiro e o próprio romance parece ter se inspirado em inúmeras autobiografias e biografias de ex-escravos e ex-escravas, publicadas em diversas partes do Atlântico, sobretudo no mundo anglófono. Essas obras, assim como as passagens de Nísia e Adèle, tinham o propósito de angariar a empatia de leitores para a causa da abolição. O romance, contudo, teve maior alcance pelo número de exemplares vendidos.

\section{A exploração de gênero das mulheres}

Em meio a autobiografias e biografias de cativos e ex-cativos presentes no universo editorial do Atlântico norte, havia um número razoável de livros que relatavam a experiência de mulheres egressas da escravidão. Nessas obras literárias, a questão da exploração de gênero das cativas ganhou destaque.

\footnotetext{
${ }^{48}$ STOWE, Harriet B. A cabana do pai Tomás. São Paulo: Clube do Livro, 1969.

${ }^{49}$ GUIMARÃES, Hélio de Seixas. Pai Tomás no romantismo brasileiro. Teresa Revista de Literatura Brasileira. São Paulo, n. 12/13, 2013, p. 422. Disponível em: https://www.revistas.usp.br/teresa/ article/view/99408. Acesso em: 06 ago. 2015. DOI: http://dx.doi.org/10.11606/issn.2447-8997. teresa.2013.99408.
} 
Talvez a mais célebre autobiografia a tratar a escravidão do ponto de vista feminino tenha sido a de Mary Prince, publicada sob o título de The history of Mary Prince, a west Indian slave, related by herself, de $1831 .^{50}$ Em seu texto, nenhuma separação fictícia de famílias escravas havia sido contada, mas a sua própria história, com cores, datas, nomes e sobrenomes que visavam convencer os leitores da veracidade do seu depoimento e persuadi-los para a causa da abolição.

Além dos temidos leilões, outra imagem marcante presente nessas biografias e autobiografias de ex-escravos era a questão da exploração que cabia particularmente às mulheres. Sojourner Truth, ex-escrava americana, preferiu calar em seu relato, "por motivos de delicadeza", a exploração íntima que vivenciou nos anos de cativeiro. Em 1850, contudo, sua companheira de infórtúnio, Harriet Jacobs decidiu expor em sua autobiografia as explorações sexuais vivenciadas enquanto fora escrava. ${ }^{51}$ Dois anos antes, portanto, do romance de Stowe, que, sem dúvida, inspirou-se nesses relatos para criar sua narrativa ficcional de sucesso. No mundo anglo-saxão, essas histórias de exploração sexual polemizaram o debate de muitos movimentos abolicionistas, ora demonstrando solidariedade às vítimas do cativeiro, ora lhes responsabilizando pelas violências sofridas. ${ }^{52}$

Certamente inspirada nessas biografias e notícias jornalísticas, Harriet B. Stowe, que não por acaso era esposa de pastor protestante, criou um discurso religioso a respeito da escravidão, condenando suas imoralidades. Ela explicita, em sua narrativa, o hediondo uso de jovens mulheres para o serviço íntimo dos senhores. O que era prática cotidiana da escravidão passa a ser representada como um crime para as leitoras e leitores de A cabana do pai Tomás. No excerto adiante, o senhor de escravos e vilão da história compra uma escrava para o "uso" de um de seus feitores:

Sambo, tornou Legree, falando a um outro negro, que se esforçava para chamar-lhe a atenção: - Você lembra do que lhe prometi? Pois aí está a mulher que comprei pra você, é sua - acrescentou, empurrando para o lado dele uma jovem mulata. - Oh! Senhor! Eu

\footnotetext{
${ }^{50}$ PRINCE, Mary. The history of Mary Prince, a west Indian slave, related by herself. Disponível em: http:// www.gutenberg.org/ebooks/17851. Acesso em: 06 ago. 2015.

${ }^{51}$ WASHINGTON, Margaret. "From motives of delicacy": sexuality and morality in the narratives of Sojourner Truth and Harriet Jacobs. The Journal of African American History, New Orleans, vol. 92, n. 1, 2007, p. 57-73. Disponível em: https://www.jstor.org/stable/20064154. Acesso em: 20 jul. 2016. ${ }^{52}$ WASHINGTON, Margaret, op. cit., p. 57-73.
} 
deixei meu marido em Nova Orléans - protestou a escrava, - E o que é que eu tenho com isso? Nada de reclamações! Aqui, o que não faltam são maridos. ${ }^{53}$

A violência sexual contra as jovens mulheres apresentou-se nas narrativas assinadas pelas próprias cativas e, na cena acima, é recriada ficcionalmente pela autora do romance. Esse clamor contra as imoralidades mobilizou mulheres de elite e classes médias de diversas sociedades, sobretudo do Atlântico norte, convencidas da urgência em se acabar com tal instituição, a despeito das várias interpretações que ofereceram ao uso particular que os senhores destinavam às mulheres sob jugo da escravidão. ${ }^{54}$ No Brasil, embora não tenhamos encontrado até o momento narrativas semelhantes de ex-escravos, muitos jornais como o Courrier du Brésil, por exemplo, republicavam como notícias ou transcreviam artigos estrangeiros relativos à escravidão em outras partes do mundo, além de produzirem narrativas ficcionalizadas de notícias reais da escravidão no Brasil.

Contudo, o debate brasileiro tomaria outras formas. Nas descrições dos leilões presenciados no Brasil dos anos 1850, Adèle Toussaint também denuncia a exploração sexual das escravas. Se na notícia da imprensa sobre a jovem grávida arrematada pelo traficante sádico da revista de Santos a descrição grotesca sugere claramente o destino de sofrimento que a jovem mãe teria nas mãos do carrasco, a ideia de violação sexual, todavia, ficava no terreno do não dito.

Na narrativa de Adèle, no entanto, a denúncia é pungente. Ela conta que sua indignação era ainda maior quando via, nos tais leilões, uma jovem mulata ser "entregue ao fazendeiro que a reservava a seu serviço íntimo, enquanto seu negrinho era algumas vezes vendido a um outro senhor". ${ }^{55} \mathrm{E}$ relata que "diante de todas essas cenas de barbárie, meu coração indignavase, cóleras generosas inflamavam-se em mim, e eu era obrigada a conter-me para não gritar a todos aqueles homens que faziam comércio de carne humana: 'carrascos!' (...) [Meus grifos]".56 Sua indignação com os "homens" responsáveis por aquele comércio evidencia, ao menos nesse excerto, uma solidariedade de gênero com as cativas, capaz de transpor fronteiras de classe, raça e nacionalidade, para responsabilizar o "sexo forte" pelos horrores dos quais

\footnotetext{
53 STOWE, Harriet B. A cabana do pai Tomás, op. cit., p. 110.

${ }^{54}$ MIDGLEY, Clare. Women against slavery..., op. cit., p. 119-152.

55 TOUSSAINT-SAMSON, Adèle. Uma parisiense no Brasil, op. cit., p. 98.

${ }^{56}$ Idem, p. 98.
} 
as mulheres eram as maiores vítimas. Deste modo, ela se aproximava novamente dos debates abolicionistas do Atlântico.

Sua reflexão era ousada para os anos 1850 no Brasil, no entanto, as memórias só vieram a público décadas depois na França, onde as ditas "imoralidades" do cativeiro e a exploração sexual eram já a grande bandeira de movimentos abolicionistas mundo afora e muitas autobiografias de ex-escravas já denunciavam as particularidades do cativeiro das mulheres. ${ }^{57}$ Parte considerável dessas denúncias reiteradas por Adèle Toussaint em suas memórias podem refletir, de alguma maneira, o sucesso do romance de Stowe em projetar de forma explícita tanto imagens literárias quanto verossímeis da exploração íntima das cativas nas páginas de A cabana do pai Tomás.

A narrativa de "Páginas de uma vida obscura", embora fortemente inspirada no texto de Stowe, se furta em tocar diretamente na questão da exploração sexual das cativas. O leitor contemporâneo à publicação da obra, contudo, poderia supor que essa seria uma das aflições pelas quais passou a mãe do filho de Domingos, descrita pelo narrador na passagem a seguir:

Era uma alma fraca que não havia podido, como a do nobre negro, permanecer intacta da abjeção a que geralmente conduz um longo cativeiro. Vendida por muitas vezes a diferentes senhores (...), a pobre escrava havia percorrido toda a escala dos sofrimentos que nas almas medíocres degenera quase sempre em vil torpor e em abnegação de todos os sentimentos de dignidade pessoal..$^{58}$

A autora se cala, mas talvez tenha deixado ao leitor a possibilidade de concluir que os sofrimentos da escrava, "vendida a diferente senhores", fossem de uma outra ordem, se comparados aos percalços da vida do varão Domingos. Contudo, a adesão à obra de Stowe por Floresta é parcial e, no caso de "Páginas", ela não chega a advogar, como a escritora americana, a abolição do cativeiro.

Se Floresta evitou o tema do "uso recreativo" das escravas na crônica, no Opúsculo humanitário de anos antes, o tema aparece, ainda que de uma outra forma. A sugestão da relação sexual entre escravas e senhores emerge mais como fruto da lascívia das negras, do que do poder de senhores: "Aos tristes inevitáveis resultados do constante viver dos meninos em contato com

\footnotetext{
${ }^{57}$ WASHINGTON, Margaret. "From motives of delicacy"..., op. cit., p. 57-73.

${ }^{58}$ FLORESTA, Nísia. Páginas de uma vida obscura. O Brasil Illustrado, Rio de Janeiro, 15/06/1855, p. 55. Disponível em: http://memoria.bn.br/DocReader/DocReader.aspx?bib=706817\&PagFis=33\&Pesq=vida\%20obscura. Acesso em: 15 jul. 2016.
} 
escravos reúnem-se outros escolhos não menos funestos à sua educação, sendo um dos mais revoltantes o pouco respeito havido entre nós para com a inocência". Não obstante, a escritora reconhece que o exemplo é dado pelos pais: "uma conduta desregrada dada por alguns pais a seus filhos".

Para falar diretamente das relações sexuais entre senhores e escravas, Nísia Floresta o faz por meio das palavras do médico francês, dr. Rendu, a quem cita: "Os jovens brasileiros são quase constantemente pervertidos ao saírem da infância; ao lado do exemplo dos pais que os têm sob os olhos, garotos e garotas, mestres e escravos passam juntos a maior parte do dia seminus; o calor do clima apressa a chegada da puberdade". ${ }^{59}$ Utilizando o raciocínio do francês, Nísia menciona explicitamente o contato íntimo entre senhores e escravas, embora não sugira a vitimização das cativas. Ao contrário, são os jovens meninos inocentes que são vítimas do mau exemplo dado pelos seus pais, sugerindo que para as escravas tais relações, ainda que assimétricas, eram desprovidas de seu caráter violento, ou mesmo indignas de menção. A recusa em vitimizar as cativas pelas relações com senhores distancia Floresta do debate que fervilhava particularmente no Atlântico norte.

Na mesma obra, ela denuncia a exploração e violência sexual contra as índias ocorridas desde o início da colonização, mas não faz o mesmo em relação às escravas. Pode-se pensar que a autora evitasse o tema devido ao público leitor do Rio de Janeiro, mas o mais provável é que Floresta aceitasse a ideia corrente de que as mulheres negras eram naturalmente mais lascivas e, por isso, participavam dessas relações íntimas voluntariamente. ${ }^{60} \mathrm{~A}$ exploração sexual das escravas era uma prática disseminada em quase todas as sociedades escravistas do século XIX. ${ }^{61}$ No caso do Brasil, muito menores eram, no entanto, os discursos que tornavam público o destino que as escravas podiam ter nas mãos de senhores ao longo dos anos $1850 .{ }^{62}$

\footnotetext{
${ }^{59}$ Minha tradução do francês. FLORESTA, Nísia. Opúsculo humanitário, op. cit., 1989, p. 99.

${ }^{60}$ XAVIER, Giovana. Entre personagens, tipologias e rótulos da "diferença": a mulher escrava na ficção no Rio de Janeiro do século XIX. In: FARIAS, Juliana Barreto; XAVIER, Giovana; GOMES, Flávio (org.). Mulheres negras no Brasil escravista e do pós-emancipação. São Paulo: Selo Negro Edições, 2012, p. 77-81.

${ }^{61}$ WASHINGTON, Margaret. "From motives of delicacy"..., op. cit., p. 57-73. Ver também o uso de escravas exclusivamente para a exploração sexual na região muçulmana de Madras em SREENIVASAM, Ramya. Drudges, dancing girls, concubines: female slaves in Rajput polity, 1500-1850. In: CHATTERJEE, Indrani E EATON, Richard M. Slavery and south Asian history. Bloomington: Indiana University Press, 2006, p. 136-161.

${ }^{62} \mathrm{O}$ movimento abolicionista utilizou as mesmas imagens no final dos anos 1870 e ao longo dos anos 1880 no Brasil. Ver: COWLING, Camillia. Conceiving freedom..., op. cit., 2013.
} 
Nísia Floresta se cala a respeito da imoralidade maior do cativeiro, mas não deixa de condenar uma outra exploração de gênero vivida pelas escravas domésticas. Em seu Opúsculo, ela critica o emprego de amas de leite, e não apenas porque advoga o aleitamento materno e considera as escravas como viciosas, mas também porque o emprego de amas de leite é um trabalho desumano, que implica na separação entre a escrava e seu filho recém-nascido, tema que aparece no romance americano de Harriet Beecher Stowe. Nísia julga as amas como pertencentes à "infeliz raça, desmoralizada pelo cativeiro e condenada à educação do chicote". E censura a ingratidão das famílias com essas mulheres, que depois de desempenhar o papel da mãe, alimentando seus filhos, veem-se maltratadas:

Não é raro ver ela [a menina] (com horror o dizemos) infligir o mais cruel tratamento à própria ama que a amamentou, a qual é alguma vez indiferentemente vendida ou alugada como um fardo inútil, apenas acaba de ser-lhe necessária. Esta revoltante ingratidão é um dos mais detestáveis exemplos dados à menina, que, tendo um dia de ser mãe, o transmite por seu turno a seus filhos. ${ }^{63}$

Na passagem acima, o olhar da escravidão é feito a partir da educação das meninas, a principal preocupação do texto. Contudo, a autora revela uma empatia com as amas de leite escravizadas, de quem reconhece a humanidade, a despeito de ressaltar sua viciosidade. Nísia se mostra simpática à sua causa, revelando uma relativa solidariedade de gênero. Ela condena um hábito extremamente disseminado, no Brasil da época, em que o número de crianças amamentadas pelas próprias mães, sobretudo nas classes sociais mais elevadas, era praticamente nulo, sendo o aluguel de amas de leite um evento tão comum quanto rentável. ${ }^{64}$ Além disso, Nísia denuncia ainda as práticas cruéis de senhoras brancas com seus escravos, ${ }^{65}$ um tema que se tornaria caro na literatura brasileira da segunda metade dos Oitocentos. ${ }^{66}$

Adèle Toussaint, como Nísia Floresta, demonstrou solidariedades com as mulheres escravizadas e revelou ser também observadora perspicaz dos

\footnotetext{
${ }_{63}$ FLORESTA, Nísia. Opúsculo humanitário, op. cit., p. 96.

${ }^{64}$ Sobre o emprego de amas de leite e mucamas ver ALENCASTRO, L. F. Vida privada e ordem privada no Império. In: ALENCASTRO, L. F. \& NOVAIS, F. (org.). História da vida privada, vol. 2. Império: a corte e a modernidade nacional. São Paulo: Companhia das Letras, 1997, p. 64.

${ }^{65}$ DUARTE, Constância Lima. Nísia Floresta: vida e obra, op. cit., p. 130-131.

${ }^{66}$ COSTA, Suely Gomes. Entre práticas escravistas e caritativas, transformações da gestualidade feminina. (Rio de Janeiro, primeira metade do século XIX). Gênero, vol. 1, 2000, p. 55-61.
} 
aspectos femininos da vida em cativeiro. Ao descrever o momento do parto, Adèle conta, com espanto, a falta de coragem das escravas e de seu sofrimento:

Assisti várias vezes ao parto daquelas infelizes. Não se deve crer que, criadas rudemente como o são, tenham mais coragem naqueles momentos do que nós brancas; de modo algum. (...) perguntei-me mais de uma vez como acontecia que aquelas criaturas, expostas a todas as intempéries das estações, que recebiam chicotadas e sofriam todas as privações, se mostrassem tão fracas diante das dores da maternidade. ${ }^{67}$

Adèle se surpreende com a fraqueza das parturientes cativas para enfrentar a dor do nascimento dos filhos e, ao fazê-lo, reforça um estereótipo que distanciava mulheres brancas das negras, ou livres das escravizadas, pois, para a autora, estas deveriam sofrer menos por estarem habituadas aos maus tratos de sua condição. Em seguida, a escritora explica ao seu público leitor francês, pouco familiarizado com a escravidão, o porquê das mesmas terem menos coragem que as "brancas" na hora do parto:

...quando colocamos um filho no mundo, o que nos sustenta em nossas dores é a ideia daquele pequeno ser que logo vamos apertar contra o peito, que amaremos, que educaremos; mas aquelas pobres escravas, de onde podem tirar coragem para levantar seu moral? Dão-se conta de que o filho que vai nascer delas está destinado à escravidão (...) de que lhes será tirado depois do nascimento (...). [a escrava em geral] não reclama sua vinda, e muitas, ao contrário, desejam-lhe a morte. Aí está o que a escravidão produz. ${ }^{68}$

Na passagem acima, Adèle se coloca na mente das negras para entender como elas podiam sentir a mesma dor e os mesmos temores que as mulheres de sua condição. Do ponto de vista da autora, apenas o desapego que as cativas tinham em relação à maternidade explicaria sua falta de coragem diante das dores.

Segundo Toussaint, enquanto para as brancas a escritora concebia uma maternidade universal que envolvia amor e dedicação incondicional aos filhos, para as negras a maternidade era, na maioria das vezes, decorrente de violações e, além disso, podia acarretar culpa e tristeza pela consciência de que reproduziam a escravidão. Isso era um triste alento para as mães que, além de sofrer com a sua condição de cativa, passariam ainda a amargar a tristeza de ver os filhos nessa situação. Pior do que isso, Adèle mostra como

\footnotetext{
${ }^{67}$ TOUSSAINT-SAMSON, Adèle. Uma parisiense no Brasil, op. cit., 2003, p. 122.

68 TOUSSAINT-SAMSON, Adèle. Uma parisiense no Brasil, op. cit., 2003, p. 122.
} 
a mãe escrava poderia ser separada dos rebentos com as vendas corriqueiras que a escravidão proporcionava.

A descrição de Adèle Toussaint parte de um pressuposto de separação fundamental entre mulheres brancas livres e escravas negras. A justificativa da diferença é a "rudeza" da vida escrava. O segundo movimento da narrativa, no entanto, é o da empatia e até mesmo da simpatia pelas mulheres que pareciam, em um primeiro momento, tão distantes dela. Suas explicações sobre a maternidade escrava acabam por concluir que a diferença entre as mulheres é situacional e ocasionada pelos malefícios da escravidão, negando uma inferioridade ou diferença natural. Mas Adèle, consciente ou não, atenta para a centralidade da mulher escrava na reprodutibilidade da escravidão, revelando também o seu poder de interromper esse ciclo reprodutivo por meio do aborto ou mesmo infanticídio.

Tanto Nísia como Adèle lançam olhares sobre as mulheres e, principalmente, mães escravizadas, revelando solidariedades de gênero que se misturam aos preconceitos da época sobre as mulheres negras, que não abordarei detidamente neste artigo. Contudo, suas escritas enviesam-se, dentre outros aspectos, pelo terreno dos assuntos femininos da escravidão e oferecem uma contribuição importante para analisar os debates sobre a escravidão dos anos 1850 no Brasil e alhures. No entanto, suas observações não param por ai.

\section{Resistindo à escravidão}

A empatia expressa por Nísia Floresta e Adèle Toussaint em relação às mulheres escravizadas, sobretudo às mães, também era tema latente na imprensa carioca da época. Fossem literários ou apenas relatos de notícias cotidianas, é possível observar escritos que denunciavam a crueldade do cativeiro a partir da denúncia dos maus tratos contra homens e mulheres e de situações resultantes do seu desespero, particularmente como o recurso ao suicídio e/ou infanticídio.

Na década de 1850, no Brasil, a preocupação com a crueldade da escravidão e com a possibilidade de escravos e escravas escaparem dessa condição por meio de soluções trágicas permeavam artigos jornalísticos cariocas como aqueles publicados pelo jornal francófono Courrier du Brésil do Rio de Janeiro. A folha era, sem dúvida, lida por Adèle, que além de leitora era uma cola- 
boradora do jornal. ${ }^{69}$ No dia 15 de fevereiro de 1857, por exemplo, o "Boletim semanal" denunciou as últimas tragédias proporcionada pela escravidão.

As cenas da escravidão que nos fornecem a imprensa nacional se renovam com frequência, ainda que ignoremos sua grande parte. Muitos podem se opor, talvez, ao alegar que os mesmos acidentes ocorrem no estado livre, o que é uma verdade a qual só nos oporemos à responsabilidade moral daqueles que são forçados a admitir mesmo que transitoriamente a escravidão. Domingo, 8 do corrente, um negro se suicidou ao se jogar ao mar na praia de S. Luzia. No dia 9 um negro se jogou ao mar novamente na praia de S. Luzia em presença de seu mestre que repousava sob os mercados da igreja em frente à praia. A morte foi instantânea. No dia 13, foi descoberto no mesmo lugar o corpo de uma negra. ${ }^{70}$

O redator contabiliza o suicídio de três negros, dois homens e uma mulher, em um período de poucos dias. O que o instigou a noticiá-los foi o horror que tal frequência provocou. Os jornalistas eram unânimes ao reconhecer a causa de tais soluções trágicas: homens e mulheres desesperados pelo cativeiro sem fim tomavam a única saída definitiva para escapar aos grilhões, a morte.

O romance de Harriet Stowe também discutiu o suicídio por meio da personagem Lúcia. Apenas informada da venda de seu filho pelo traficante do barco, a personagem escravizada Lúcia, companheira de infortúnio de Tomás, já desesperada pela separação da família, não suporta a perda do filho para a escravidão: "Horas mais tarde, [Tomás] acordou sobressaltado quando um vulto escuro passou, râpidamente [sic], à sua frente, e um baque surdo se fêz [sic] ouvir na água. Olhando em tôrno [sic], viu que Lúcia havia desaparecido". ${ }^{71}$ Tanto homens como mulheres escravizados recorriam ao suícidio para escapar da escravidão, mas, no meado do século, literatura e imprensa tinham uma preferência pelas suícidas como Lúcia.

\footnotetext{
${ }^{69}$ MAIA, Ludmila de Souza. Viajantes de saias..., op. cit.

70 "Les scènes de l'esclavage que nous empruntons à la presse nationale se renouvellent assez fréquemment, bien qu'on ignore la plus grand partie. On nous objectera, peut-être, que les mêmes accidents se reproduisent dans l'état libre, ce qui est une vérité à laquelle nous n'objecteron que la responsabilité morale de ceux qui sont forcés d'admettre, même transitoirement l'esclavage. Dimanche, 8 du courant un noir s'est suicidé en se jetand à la mer sur le rivage de S. Luzia. Le 9 un noir se jetait à la mer encore à la plage S. Luzia en présence de son maître qui prenait du repos sur les marches de l'église située en face du rivage. La mort a été instantanée. Le 13 on a découvert au même endroit le corps d'une négresse". Courrier du Brésil, Rio de Janeiro, 15/02/1857. Disponível em: http://memoria.bn.br/DOCREADER/docreader.aspx?BIB=709719. Acesso em: 03/04/2014.

${ }^{71}$ STOWE, Harriet B. A cabana do pai Tomás, op. cit.
} 
No mesmo Courrier de 15 de fevereiro de 1857, a sessão de poesia do jornal relembra o desespero de uma escrava real que se atirou ao mar com o filho:

Nós relatamos há quinze dias uma tentativa de suicídio por uma negra que se jogou ao mar depois de ter lançado o seu filho. Nós citamos as palavras que ela pronunciou na ocasião de seu salvamento enquanto recobrava seus sentidos: "eu quero morrer, dizia ela, com meu filho, antes do que vê-lo escravo como eu"72

A potencial suicida e infaticida via na morte a possibilidade de libertação de si e do filho. O jornalista chega mesmo a construir o discurso da escrava na hora da tentativa de suicídio. A força retórica da citação mais uma vez parece beber em obras literárias para conceder dramaticidade à situação. O toque romanesco devia-se, entre outros aspectos, ao gênero das suicídas. $\mathrm{O}$ ato de desespero conectava-se, ou era assim concebido socialmente, à sua condição de mulher, seja pela ameaça à honra, concretizada no temor da violação sexual; seja pela maternidade, no caso da separação dos filhos. $\mathrm{O}$ resultado ficcionalizado dava-se por meio do suicídio ou, em casos ainda mais extremos do infanticídio dos filhos.

Nísia Floresta não descreve nenhum suicídio ou infanticídio em suas obras dos anos 1850, mas demonstra, por meio da personagem Maria, a amada de Domingos, na crônica "Páginas de uma vida obscura", o definhamento da pobre escrava, causada pelo sofrimento e tristeza, a despeito de sua juventude. Maria não se mata, mas se deixa morrer, sendo consumida pelo definhamento do corpo e da alma. No caso do trabalhador escravizado na pedreira, da crônica "Passeio ao aqueduto da Carioca", embora não se fale em suicídio, o próprio escravo reconhece que sua vida em cativeiro se configura uma morte social. O suicídio era considerado uma temática anticristã e Nísia costumava evitar temas imorais de sua escrita e, talvez por isso, tenha evitado a representação do suicídio como fuga da escravidão.

No caso de Adèle, a passagem sobre as parturientes explicita ao menos o desejo de não procriar, por meio do aborto, recusando reproduzir seu sofrimento e testemunhar a escravidão dos filhos. Além disso, em seu relato de viagem ao Rio de Janeiro, ela publica, em anexo, a tradução para o francês

\footnotetext{
72 "Nous avons ranconté il y a quinze jours une tentative de suicide par une négresse qui s'était jetée à la mer après y avoir lancé son enfant. Nous avons cités les paroles qu'elle prononça lorsqu'après avoir été sauvée elle recouvra l'usage de ses sens. 'Je veux mourir, disait-elle, avec mon enfant, plutôt que de le voir esclave comme moi'". Courrier du Brésil, Rio de Janeiro, 15/02/1857. Disponível em: http://memoria.bn.br/DOCREADER/ docreader.aspx?BIB=709719. Acesso em: 03 apr. 2014.
} 
do poema intitulado "O escravo" de Luiz Fagundes Varella, que justamente nos fala da morte como forma de libertação dos cativos: "Se vivo, foste escravo, morto es livre pela lei suprema".73 Coincidência talvez, mas mostra que Adèle simpatizava com o sofrimento dos cativos e estava atenta à associação entre escravidão e suicídio, ainda que não tenha abordado diretamente o tema em seu próprio texto.

A ideia de que as mulheres poderiam recorrer à própria morte e ao assassínio de seus filhos como forma de se libertar da opressão da escravidão parecia ser tema da literatura e da imprensa dos anos 1850, no Brasil e alhures, e essas imagens tiveram diferentes interpretações, bem como serviram a diferentes propósitos. O fim do tráfico em 1850 pode ter impulsionado uma nova obsessão pelas mulheres escravizadas e seu corpo, ou ainda pela sua capacidade reprodutiva. No caso dos homens, o suicídio ameaçava em menor proporção a continuidade da escravidão e eles eram menos associados a casos de infanticídio, tanto na literatura quanto na imprensa. A brutalidade dos castigos físicos, geralmente, era destinada aos homens, assim como seus atos de agressões e crimes contra a vida. O suicídio, no caso deles, era mais raramente descrito ou ficcionalizado. No caso das mulheres, o temor do suicídio trazia a dúvida sobre o futuro da escravidão. A centralidade da mulher na reprodução da escravaria tornava esses discursos de denúncia de suicídios ambíguos, uma vez que buscava a empatia de leitores para a causa das vítimas da escravidão, fosse porque desejassem o fim da instituição, fosse porque a crueldade poderia por termo a existência dos próprios escravos, sendo imperativo o tratamento humano dos cativos, e, sobretudo, das cativas.

\section{Conclusão}

As visões das autoras oscilavam entre um extremo e outro, mostrando uma forma paradoxal de se pensar os escravos e o cativeiro, contradição que pertencia a sua própria época. Se as duas autoras condenavam os horrores da escravidão, demonstraram empatia pelos escravos e, particularmente, pelas cativas, elas também revelariam nos textos da ou sobre a década de 1850 uma visão extremamente negativa desses indivíduos. Eles foram considerados degenerados, feios, sujos, moralmente viciados, hipersexualizados, inferiores e animalizados. Ao mesmo tempo, Nísia e Adèle também os defen-

\footnotetext{
75 TOUSSAINT-SAMSON, Adèle. Une parisienne au Brésil. Avec photographies originales. Paris: Paul Ollendorff, 1883. BNF, Rez-du-Jardin, Paris, p. 224.
} 
deram e justificaram seu estado de miséria e vício como resultado da escravização ao qual estavam submetidos, perdoando suas faltas. Elas lançaram olhares complacentes, solidários e benevolentes às suas dores, mostrando compartilhar a contradição de muitos contemporâneos em relação aos escravos e ao cativeiro. ${ }^{74}$

Através da história de Domingos, no lamento do escravo na pedreira da Glória ou nas passagens de seu tratado sobre a educação das meninas no Brasil, Nísia jamais defendeu explicitamente a abolição, como nos aponta Charlotte Matthews. ${ }^{75}$ Ao contrário, Floresta condenou a escravidão pela sua desumanidade e criticou os maus senhores, que exploravam desmedidamente os cativos. ${ }^{76}$ Domingos serviu até o fim dos seus dias, teve prazer em servir e nunca lhe foi dado nada em troca pelo seu "bom senhor". O escravo da pedreira lamentou que trabalharia de forma extenuante até sua morte e, no tratado de educação, Floresta advogou a retirada dos escravos de dentro da casa da família brasileira, mas nada disse sobre as ruas e plantações. Como nos aponta Matthews, ao final, Nisia parece ter advogado pela extinção de maus senhores e pela humanização da escravidão, ${ }^{77}$ possivelmente porque o fim do tráfico e a impossibilidade de importar novos cativos poderia por um fim à instituição escrava. Não é possível saber no que, de fato, ela acreditava, mas a defesa da abolição aconteceu apenas quando Floresta se mudou em definitivo para a Europa no final dos anos 1850 e quando não mais dependia do trabalho escravo em seu cotidiano. Seu silêncio sobre a abolição no Brasil dos anos 1850 pode tanto ser revelador de um silêncio deliberado da autora que evitava se indispor com a opinião pública brasileira, quanto sua firme convicção de que a escravidão deveria seguir de forma humanizada.

Adèle Toussaint também condenou os tratamentos brutais destinados aos negros e julgou a escravidão como uma característica incivilizada do Brasil. Ela descreveu a paisagem do Rio de Janeiro com sua multidão de escravos, observou com cuidado cenas que revelavam a exoticidade da sociedade escravista brasileira, ao mesmo tempo em que examinou a vida cotidiana dos cativos, simpatizando com sua sorte ou criticando-os por sua inferioridade. Ela justificou, ainda, a escravidão como única forma de trabalho possível, naquele momento, devido ao clima tórrido dos trópicos. De-

\footnotetext{
${ }^{74}$ Como o exemplo de José Bonifácio. Ver CHALHOUB, Sidney. A força da escravidão..., op. cit., p. 42-43.

${ }^{75}$ MATTHEWS. Charlotte. Gender, race and patriotism in the works of Nísia Floresta, op. cit., p. 130.

${ }^{76}$ DUARTE, Constância Lima. Nísia Floresta: vida e obra, op. cit., p. 133.

77 DUARTE, Constância Lima. Nísia Floresta: vida e obra, op. cit., p. 139.
} 
fendeu o imperador da responsabilidade de manter o cativeiro, pintando-o como um bom senhor que, no entanto, não fora capaz de mudar os costumes antigos e arraigados do país de uma hora para outra e foi, portanto, obrigado pela sociedade brasileira a "fechar os olhos ao tráfico de negros". Segundo a escritora francesa, apenas os negros poderiam "suportar os trabalhos de cultura sob aquele sol de fogo". E afirma que as tentativas de trazer colonos de outros países não obtiveram sucesso. ${ }^{78}$ A sistematização de sua obra foi bem posterior ao período em que viveu no Rio de Janeiro e, mesmo assim, continuava a defender a dependência do país e de seu "bondoso imperador" do trabalho escravo e, de certo modo, apoiando o prolongamento da escravidão no Brasil. ${ }^{79}$ Contudo, o apoio da autora não pode ser desligado do fato de o imperador ter contribuído para a ascensão econômica dos Toussaint na Corte imperial, através do emprego de Jules como instrutor de dança das princesas imperiais e de sua subsequente pensão que continuou a receber, mesmo quando retornou à França. ${ }^{80}$

No Brasil dos anos 1850, a abolição do cativeiro não estava na ordem do dia e as descrições de separações de famílias pela venda de escravos e da exploração de gênero das mulheres cativas poderiam ter um sentido diverso das lutas antiescravidão. Ao contrário, as críticas à escravidão sugerem a necessidade de humanizá-la, com o intuito mesmo de prolongar sua existência através da reprodução interna do número de escravos, no pós-abolição do tráfico atlântico. A crueldade da separação de famílias, em especial de mães e filhos, não seria apenas maléfica para os próprios indivíduos escravizados, mas poderia afetar a reprodutibilidade do número de cativos e a própria existência da escravidão, posto que a importação de negros da África estava fora de questão. ${ }^{81}$

\footnotetext{
${ }^{78}$ MATTHEWS. Charlotte. Gender, race and patriotism in the works of Nísia Floresta, op. cit., p. 99.

79 Ana Maria Mauad discute em seu texto a autoimagem difundida pelo próprio imperador e comprada por muitos de seus biógrafos contemporâneos. Ele construiu para si a imagem de bom velhinho dedicado à ciência e à família. Cf. MAUAD, Ana Maria. Imagem e autoimagem do Império. In: ALENCASTRO, L. F. E E NOVAIS, F. (org.). História da vida privada, vol. 2, Império: a corte e a modernidade nacional. São Paulo: Companhia das Letras, 1997, p. 181-232.

80 “Collegio Pedro II. O mesmo José Lourenço de Paiva está também professor de dansa do Externato com exercício desde 9 de fevereiro de 1866, por demissão que pediu e obteve Julio Toussaint em 8 do mesmo fevereiro". Ver BRASIL. Ministério do Império - 1832 a 1888. Relatório da inspetoria geral da instrução primária e secundária do Municipio da corte para o ano de 1865. Apresentado Ao Illm. e Exm. Sr. Marquez de Olinda, Ministro e secretario de estado dos negócios do Imperio. Ed. 1, p. 81. Disponível em: www.bn.br/hemerotecadigital. Acesso em: 01 jun. 2015.

${ }^{81}$ MATTHEWS, Charlotte. Gender, race and patriotism in the works of Nísia Floresta, op. cit., p. 134, 145.
} 
Ao discutirem a questão, Nísia e Adèle se engajaram em uma das mais importantes questões da política, da sociedade e da economia brasileira da década de 1850: o futuro da escravidão. Ao fazê-lo, encetaram diálogos que extrapolaram as fronteiras nacionais, discutindo uma das questões mais polêmicas do Atlântico. Suas leituras da questão escrava se pautam por um olhar que enfatiza, particularmente, questões relativas ao gênero dos indivíduos escravizados, dando ênfase também à questão da mulher negra escravizada e a assuntos considerados pelos contemporâneos como femininos, como a família. Como autoras que defendiam em suas obras o lugar de mãe e esposa como papéis fundamentais para as mulheres, elas dedicaram parte de seus escritos a descrever a vida dessas outras mulheres, separadas pelo abismo do estatuto jurídico brasileiro e racial que as prendiam ao cativeiro. Assim como muitos textos jornalísticos e literários contemporâneos, as autoras reproduziram a tensão entre anseios contrários à instituição escrava que ecoavam particularmente no Atlântico norte, combinando-os com impressões derrogatórias dos negros, bem como com preocupações da sociedade brasileira de manter a instituição escrava por meio da humanização do cativeiro com o intuito de aumentar a reprodutibilidade dos cativos e prolongar a escravidão. A ideia de evitar cenas de separação familiar, como a do leilão que inicia esse artigo, refletia uma das várias contradições nas quais a própria sociedade brasileira estava imersa naquele meado de século. Floresta e Toussaint fizeram parte do debate, dando particular atenção à questão das mulheres no cativeiro, revelando formas de solidariedade e empatia de gênero, bem como reiterando estereótipos de hipersexualidade, animalização e inferioridade de homens e mulheres que viveram sob o jugo da escravidão.

Neste artigo, pretendi discutir as perspectivas de gênero sobre a escravidão no Brasil na década de 1850 esboçadas pelas autoras Toussaint e Floresta e sua centralidade nos debates sobre a escravidão no período. Através do diálogo de suas obras com outros textos ficcionais e não-ficcionais de meados dos Oitocentos sobre a escravidão no Brasil e em outras partes do Atlântico, quis demonstrar como as interpretações de gênero na escravidão oscilaram paradoxalmente entre opiniões contrárias à escravidão, ao mesmo tempo em que constituíram também discursos favoráveis ao prolongamento do cativeiro, como um mal irremediavelmente necessário à sociedade brasileira. Quaisquer que fossem os propósitos, tais escritos de meados dos Oitocentos são reveladores da emergência de uma nova sensibilidade crítica em relação à escravidão. 


\section{Referências bibliográficas}

\section{Fontes}

\section{Archives departamentales de la Seine-Maritime}

Certidão de óbito de Nísia Floresta Brasileira Augusta. Registres Paroissiaux et d'État civil, Mariages, décès, naissance, Décès n. 28, 1885. Archives departamentales de la Seine-Maritime, Bonsecours-dit Blosseville, Disponível em: http:// recherche.archivesdepartementales76.net/?id=viewer\&doc=accounts\%2Fmnesys_ad76\%2Fdatas\%2Fir\%2Fserie_E_seigneuries_familles_notaires_etat_civil\%2FFRAD076_IR_E_etat_civil\%2ExmlE. Acesso em: 20 jan. 2015.

\section{Biblioteca Nacional}

Brasil. Ministério do Império - 1832 a 1888. Relatório da inspetoria geral da instrução primária e secundária do Municipio da corte para o ano de 1865. Apresentado Ao Ilm. ${ }^{\circ}$. e Exmo. Sr. Marquez de Olinda, Ministro e secretario de estado dos negócios do Império. Ed. 1, p. 81. Disponível em: www.bn.br/ hemerotecadigital Acesso: em 01 jun. 2015.

Courrier du Brésil, Rio de Janeiro, 18/05/1856. Disponível em: http://memoria.bn.br/ DOCREADER/docreader.aspx?BIB=709719. Acesso em: 03 abr. 2014.

Courrier du Brésil, Rio de Janeiro, Edição 7, 15/02/1857; Edição 20, 18/05/1856; Edição 34, 21/08/1859. Disponível em: http://memoria.bn.br/DocReader/docreader. aspx?bib=709719\&pasta=ano\%20185\&pesq= Acesso em: 03 fev. 2014.

Courrier du Brésil, Rio de Janeiro, 15/02/1857. Disponível em: http://memoria.bn.br/ DOCREADER/docreader.aspx?BIB=709719. Acesso em: 03 fev. 2014.

Diário de Pernambuco, Recife, 12/09/1828. Disponível em: www.memoria.bn.br Acesso em: 02 fev. 2014.

O Brasil Illustrado, Rio de Janeiro, 31/03/1855, 15/04/1855, 30/04/1855, 15/05/1855, 31/05/1855, 16/06/1855, 30/06/1855, 15/07/1855. Disponível em: www.bn.br/ hemerotecadigital. Acesso em: 03 fev. 2014.

FLORESTA, Nísia. Páginas de uma vida obscura. O Brasil Illustrado, Rio de Janeiro, 31/03/1855, 15/04/1855, 30/04/1855, 15/05/1855, 31/05/1855, 16/06/1855, 30/06/1855. Disponível em: www.bn.br/hemerotecadigital. Acesso em: 03 fev. 2014.

Passeio ao aqueduto da Carioca. O Brasil Illustrado, Rio de Janeiro, 15/07/1855. Disponível em: www.bn.br/hemerotecadigital Acesso em: 01 jun. 2015.

Publicações a pedido. Diário do Rio de Janeiro, Rio de Janeiro, 17/02/1852. Disponível em: www.bn.br/hemerotecadigital. Acesso em: 01 jun. 2015.

\section{Arquivo da Câmara dos Deputados}

Art. $2^{\circ}$ do Decreto 1.695, 15/09/1869. Art. $4^{\circ}$ da Lei no 2040, 28/09/1871. Disponível em: http://www2.camara.leg.br/legin/fed/decret/1824-1899/decreto-1695-15setembro-1869-552474-publicacaooriginal-69771-pl.html; http://www.planalto. gov.br/ccivil_03/leis/LIM/LIM2040.htm. Acesso em: 06 abr. 2016. 


\section{Fontes publicadas}

AUGUSTA, Nísia Floresta Brasileira. Direitos das mulheres e injustiça dos homens. $4^{\mathrm{a}}$ edição. São Paulo: Cortez, 1989.

FLORESTA, Nísia. Opúsculo humanitário. Introdução e notas de Peggy Sharpe-Valadares. São Paulo: Cortez Editora, 1989.

Páginas de uma vida obscura. In: DUARTE, Constância (org.). Inéditos e dispersos de Nísia Floresta. Natal: EdUFRN, 2009.

EXPILLY, Charles. Mulheres e costumes do Brasil. São Paulo: Companhia da Editora Nacional, 1935.

PFFEIFFER, Ida. Voyages autour du monde. Paris: Hachette et Cie, 1876.

PRINCE, Mary. The history of Mary Prince, a West Indian slave, related by herself. Disponível em: http://www.gutenberg.org/ebooks/17851. Acesso em: 06/08/2015.

STOWE, Harriet B. A cabana do pai Tomás. São Paulo: Clube do Livro, 1969.

TOUSSAINT-SAMSON, Adèle. Une parisienne au Brésil. Avec photographies originales. Paris: Paul Ollendorff, 1883. BNF, Rez-du-Jardin, Paris.

. Uma parisiense no Brasil. Rio de Janeiro: Typographia de J. Villeneuve, 1883.

. Uma parisiense no Brasil. Tradução de Maria Lúcia Machado. Rio de Janeiro: Editora Capivara, 2003.

\section{Bibliografia}

ALENCASTRO, Luiz Felipe $\&$ NOVAIS, Fernando (org.). História da vida privada, vol. 2 Império: a corte e a modernidade nacional. São Paulo: Companhia das Letras, 1997.

. Vida privada e ordem privada no Império. In: ALENCASTRO, Luiz Felipe $\mathcal{E}$ NOVAIS, Fernando (org.). História da vida privada, vol. 2 Império: a corte e a modernidade nacional. São Paulo: Companhia das Letras, 1997.

AZEVEDO, Célia Maria Marinho de. Abolicionismo, Estados Unidos e Brasil, uma história comparada (século XIX). São Paulo: Annablume, 2003.

. Onda negra medo branco. O negro no imaginário das elites - século XIX. São Paulo: Paz e Terra, 1987.

CHALHOUB, Sidney. A força da escravidão: ilegalidade e costume no Brasil oitocentista. São Paulo: Companhia das Letras, 2012.

História contada: capítulos de história social da literatura brasileira. Rio de Janeiro: Nova Fronteira, 1998.

CHATTERJEE, Indrani \& EATON, Richard M. Slavery and south Asian history. Bloomington: Indiana University Press, 2006.

CONRAD, Robert. The destruction of Brazilian slavery, 1850-1888. Malabar, FL: Krieger Publishing, 1993.

COSTA, Suely Gomes. Entre práticas escravistas e caritativas, transformações da gestualidade feminina. (Rio de Janeiro, primeira metade do século XIX). Gênero, vol. 1, 2000, p. 55-61. 
COWLING, Camillia. Conceiving freedom. Women of color, gender, and the abolition of slavery in Havana and Rio de Janeiro. Chapel Hill: The University of North Caroline Press, 2013.

O fundo de emancipação "Livro de ouro" e as mulheres escravizadas: gênero, abolição e os significados da liberdade na Corte, anos 1880. In: CÔRTES, Giovanna; FARIAS, Juliana; GOMES, Flávio (org.). Mulheres negras no Brasil escravista e do pós-emancipação. São Paulo: Selo Negro Edições, 2012, p. 213-226.

DUARTE, Constância Lima (org.). Inéditos e dispersos de Nísia Floresta. Natal: EdUFRN, 2009. Nísia Floresta: vida e obra. 2a edição. Natal: EdUFRN, 2008.

El YOUSSEF, Alain. Imprensa e escravidão: política e tráfico negreiro no Império do Brasil (Rio de Janeiro, 1822-1850). São Paulo: Intermeios, Fapesp, 2016.

FARIAS, Juliana Barreto; XAVIER, Giovana; GOMES, Flávio (org.). Mulheres negras no Brasil escravista e do pós-emancipação. São Paulo: Selo Negro Edições, 2012.

FLORES, Hilda Hubner. Nísia Floresta Brasileira Augusta. Letras de Hoje, vol. 27, n. 3, Porto Alegre, 1992, p. 101-113. Disponível em: http://revistaseletronicas.pucrs. br/fo/ojs/index.php/fale/article/view/16073/10546. Acesso em: 13/07/2015.

GUIMARÃES, Hélio de Seixas. Pai Tomás no romantismo brasileiro. Teresa Revista de Literatura Brasileira, n. 12/13, São Paulo, 2013, p. 421-429. Disponível em: http:// www.revistas.usp.br/teresa/article/view/99408. Acesso em: 06 ago. 2015. DOI: http://dx.doi.org/10.11606/issn.2447-8997.teresa.2013.99408.

HUNT, Lynn. A invenção dos direitos humanos. Uma história. São Paulo: Companhia das Letras, 2009.

JOHNSON, Walter. Soul by soul: life inside the antebellum slave market. Cambridge e Londres: Harvard University Press, 1999.

JOHNSON, Walter (org.). The chattel principle: internal slave trade in the Americas. New Haven e Londres: Yale University Press, 2004.

MAIA, Ludmila de Souza. Viajantes de saias: escritoras e ideias antiescravistas numa perspectiva transnacional (Brasil, século XIX). Revista Brasileira de História, vol. 34, nº 68, São Paulo, p. 61-81, 2014.

. Viajantes de saias: gênero, literatura e viagem em Adèle Toussaint-Samson e Nísia Floresta (Europa e Brasil, século XIX). Tese de doutorado em História Social, Instituto de Filosofia e Ciências Humanas, Universidade Estadual de Campinas, 2016.

MARQUESE, Rafael; PARRON, Tâmis; BERBEL, Márcia. Slavery and politics: Brazil and Cuba, 1790-1850. Albuquerque: University of New Mexico Press, 2016.

MATTHEWS. Charlotte. Gender, race and patriotism in the works of Nisia Floresta. Woodbridge: Tamesis, 2012.

MAUAD, Ana Maria. Imagem e autoimagem do Império. In: ALENCASTRO, Luiz Felipe $\mathcal{E}$ NOVAIS, Fernando (org.). História da vida privada, vol. 2 Império: a corte e a modernidade nacional. São Paulo: Companhia das Letras, 1997, p. 181-232.

MIDGLEY, Clare. Women against slavery: the British campaigns, 1780-1870. Londres e Nova York: Routledge, 1992. 
RIBEIRO, Aline Vítor. Harriet Beecher Stowe e Nísia Floresta: abolição e traduções culturais nos Estados Unidos e Brasil. In: ENCONTRO INTERNACIONAL DA ANPHLAC, XI, 2014, Niterói. Anais. São Paulo, USP, 2014. Disponível em: http:// anphlac.fflch.usp.br/sites/anphlac.fflch.usp.br/files/Aline\%20Vitor\%20Ribeiro. pdf. Acesso em: 20/07/2016.

ROCHA, Karolina Fernandes. Mensageiras da liberdade: mulheres, abolicionismo e recrutamento militar (província do Espirito Santo, 1836-1888). Dissertação de mestrado em História Social das Relações Políticas, Centro de Ciências Humanas e Naturais, Universidade Federal do Espírito Santo, 2016.

SREENIVASAM, Ramya. Drudges, dancing girls, concubines: female slaves in Rajput polity, 1500-1850. In: CHATTERJEE, Indrani \& EATON, Richard M. Slavery and south Asian history. Bloomington: Indiana University Press, 2006, p. 136-161.

SLENES, Robert. The Brazilian internal slave trade, 1850-1888. Regional economies, slave experience, and the politics of a peculiar market. In: JOHNSON, Walter (org.). The chattel principle: internal slave trade in the Americas. New Haven e Londres: Yale University Press, 2004, p.325-370.

THERENTY, Marie-Eve. Pour une histoire litteráire de la presse au XIXe siècle. Revue d'histoire littéraire de la France, n. 3, 2003, p. 625-635. Disponível em: https:// www.cairn.info/revue-d-histoire-litteraire-de-la-france-2003-3-page-625.htm. Acesso em: 20 jul. 2016. DOI: 10.3917/rhlf.033.0625.

Vies drôles et "scalps de puce": des microformes dans les quotidiens à la delle Époque. Études françaises, vol. 44, n. 3, 2008, p. 57-67. Disponível em: https://www.erudit.org/fr/revues/etudfr/2008-v44-n3-etudfr2544/019532ar/. Acesso em: 20 jul. 2016. DOI: http://dx.doi.org/10.7202/019532ar

XAVIER, Giovana. Entre personagens, tipologias e rótulos da "diferença": a mulher escrava na ficção no Rio de Janeiro do século XIX. In: FARIAS, Juliana Barreto; XAVIER, Giovana; GOMES, Flávio (org.). Mulheres negras no Brasil escravista e do pós-emancipação. São Paulo: Selo Negro Edições, 2012, p. 77-81.

WASHINGTON, Margaret. "From motives of delicacy": sexuality and morality in the narratives of Sojourner Truth and Harriet Jacobs. The Journal of African American History. New Orleans, vol. 92, n. 1, 2007, p. 57-73. Disponível em: https://www. jstor.org/stable/20064154. Acesso em: 20/07/2016.

Recebido: 23/04/2017 - Aprovado: 24/10/2017 